\title{
Pancreatic Neuroendocrine Tumor pT2 TNM Finding v8
}

National Cancer Institute

\section{Source}

National Cancer Institute. Pancreatic Neuroendocrine Tumor PT2 TNM Finding v8. NCI

Thesaurus. Code C135553.

Pancreatic neuroendocrine tumor limited to the pancreas and measuring 2-4 cm. (from AJCC 8th Ed.) 